Journal of Extension Education

Vol. 28 No. 1, 2016

\title{
Performance Analysis of Self Help Groups on Farm Entrepreneurship in Thiruvananthapuram District of Kerala
}

\author{
Suma Rose Sundaran ${ }^{1}$ and G.S. Sreedaya ${ }^{2}$
}

\begin{abstract}
The present study aims to analyse the performance of the (Self Help Groups) involved in farm entrepreneurship in terms of managerial efficiency, sustainability and entrepreneurial behaviour of SHGs. Ninety respondents were selected randomly from three men and women SHGs involved in fruit and vegetable cultivation from six different blocks of Keral athrough purposive and simple random sampling. A well-structured interview schedule was used for data collection. Managerial efficiency and entrepreneurial behaviour was measured using the procedure developed by Sreedaya (2000) and Kumar (2007) respectively and sustainability was measured using the procedure developed by the researcher for the study. The results were analysed with the help of different statistical tools like mean, frequency, percentage and ANOVA.The result revealed that majority of the men and women respondents had medium level of managerial efficiency, sustainability and entrepreneurial behaviour. It was also revealed that there was no significant difference between men and women SHGs in terms of managerial efficiency and sustainability but they differ only in terms of entrepreneurial behavior.
\end{abstract}

Keywords : Farm entrepreneurship, managerial efficiency, sustainability, entrepreneurial behaviour, SHGs

\section{INTRODUCTION}

Agriculture and allied sectors are considered to be the mainstay of the Indian economy. Entrepreneurship forms a key factor for the survival of small scale farming in this changing global economy. Entrepreneur is one who always searches for change, responds to it and exploits it as an opportunity (Drucker, 1985).
Entrepreneurship is described as the process through which entrepreneurs create and grow enterprises (Dabson and Malkin, 2003). Farmer entrepreneurs are the ones who see their farms as a means of earning profits (Kahan, 2012). Pandey in 2013 reported that agriculture have several areas of entrepreneurship

1-PG Scholar and 2 - Assistant Professor, Department of Agricultural Extension, College of Agriculture, Kerala Agricultural University, Vellayani-695522, Thiruvananthapuram, Kerala.

Received : 1-9-2016; Accepted : 16-9-2016 
opportunities like dairy, sericulture, goat rearing, rabbit rearing, floriculture, fisheries, shrimp farming, sheep rearing, vegetable cultivation, nursery farming and farm forestry. NABARD (1995) defined SHG as a homogenous group of rural poor voluntarily formed to save whatever amount they can conveniently save out of their earnings and mutually agree to contribute to a common fund from which lend to members for productive and emergent credit needs. Managerial efficiency is the ability of the farmers in effective planning, production and marketing of produce. Sustainability is defined as the extent to which the group is viable after the withdrawal of the promoters.Entrepreneurial behaviour is defined as the human behaviour involved in identifying and exploiting opportunities through creating and developing new ventures. With this background, the present study was conducted to analyse the performance of the SHGs involved in farm entrepreneurship in terms of managerial efficiency, sustainability and entrepreneurial behaviour and twelve profile characteristics namely age, annual income, market perception, self confidence, social participation, goal setting, dealing with failure behaviour, personal initiative and responsibility, use of resources, problem solving ability, assertiveness and work commitment were selected as independent variables after judges rating.

\section{METHODOLOGY}

The study was conducted in six panchayaths from the selected six blocks namely Kazhakootam. Poovachal and Kalliyoor for men SHG sand Manikal, Ottoor and Pallichal for women SHGs. From each selected SHGs, fifteen members were randomly selected for the study. Thus a total of ninety espondents were included in the present study. A wellstructured interview schedule was used for data collection from the respondents. The results were analysed with the help of different statistical tools like mean, frequency, percentage and ANOVA

\section{FINGINGS AND DISCUSSION \\ Managerial Efficiency}

Table 1 reveals that 66.67 per cent of men respondents and 60 percent of women respondents exhibited medium level of managerial efficiency. The managerial efficiency was measured in terms of planning, production and marketing aspects of SHGs which in turn depend on the profile characteristics such as market perception, self confidence, goal setting, social participation, use of resources and problem solving ability. In all these seven profile characteristics selected, men respondents were in a better position than the women respondents which may be the reason for better managerial efficiency of men SHG members. Moreover the land holdings of women SHGs were less compared to men which may be another reason for reduced managerial efficiency of the women respondents. 
Table 1. Distribution of the Respondents Based on Managerial Efficiency $(n=45)$

\begin{tabular}{|c|l|c|c|l|c|c|}
\hline \multirow{2}{*}{ S1.No. } & \multirow{2}{*}{ Category } & \multicolumn{2}{|c|}{ Men (n=45) } & \multirow{2}{*}{ Category } & \multicolumn{2}{c|}{ Women } \\
\cline { 3 - 4 } \cline { 3 - 6 } & & $\mathbf{F}$ & $\%$ & & F & $\%$ \\
\hline 1 & Low & 7 & 15.56 & Low & 9 & 20 \\
\hline 2 & Medium & 30 & 66.67 & Medium & 27 & 60 \\
\hline 3 & High & 8 & 17.77 & High & 9 & 20 \\
\hline & Mean $=49.8$ & & Mean $=47.95$ & & \\
& SD $=78.89$ & & SD $=71.17$ & & \\
\hline
\end{tabular}

F-Frequency, \%- Percentage

\section{Sustainability}

Men SHGs (62.23\%) seem to be more sustainable than women SHGs $(51.12 \%)$ which is evident from table 2.Sustainability depends on wise use of resources and problem solving ability.
The SHGs can sustain only if they use the resources wisely and face the problems encountered by them. The study revealed that the men respondents were better in judicious use of resources and problem solving ability.

Table 2. Distribution of the Respondents Based on Their Opinion Regarding the Sustainability of Group.

\begin{tabular}{|c|c|c|c|c|c|c|}
\hline \multirow{2}{*}{ S1.No. } & \multirow{2}{*}{ Category } & \multicolumn{2}{|c|}{ Men $(n=45)$} & \multirow{2}{*}{ Category } & \multicolumn{2}{|c|}{ Women $(n=45)$} \\
\hline & & $\mathbf{F}$ & $\%$ & & $\mathbf{F}$ & $\%$ \\
\hline 1 & Low $(<Q 1)$ & 12 & 26.66 & Low $(<Q 1)$ & 9 & 20.00 \\
\hline 2 & Medium (Q1 - Q3) & 28 & 62.23 & Medium (Q1 - Q3) & 23 & 51.12 \\
\hline 3 & High (>Q3) & 5 & 11.11 & High (>Q3) & 13 & 28.88 \\
\hline & $\mathrm{Q} 1=61 \mathrm{Q} 3=71$ & & & $\mathrm{Q} 1=62, \mathrm{Q} 3=71$ & & \\
\hline
\end{tabular}

F-Frequency, \%- Percentage

\section{Entrepreneurial Behaviour}

It is clear from table 3 that 60 percent of men respondents and 53.34 percent of women respondents exhibited medium level of entrepreneurial behaviour. The researcher could find out during the field visit that men SHG members were willing to adopt innovative farming practices like cultivation of grafted chilly, cabbage etc. On the other hand. women farmers were hesitant to adopt innovative activities of cultivation. This may be because of the fact that men SHG members were cultivating on commercial scale whereas women were only confined to subsistence farming. 
Performance Analysis of Self Help Groups on Farm Entrepreneurship in Thiruvananthapuram District of Kerala

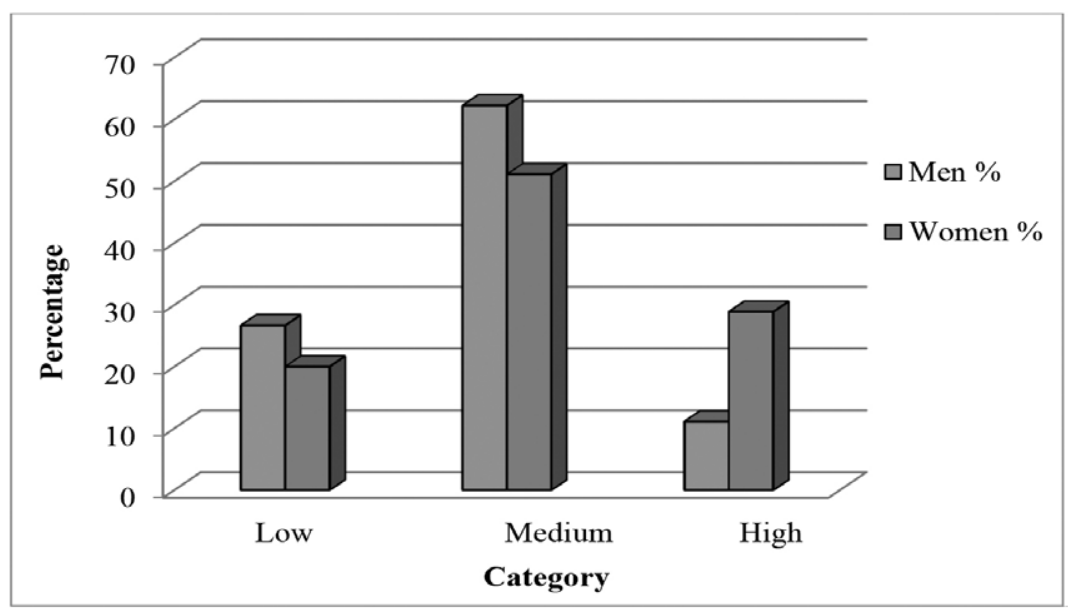

Fig 2. Distribution of Respondents Based on their Opinion Regarding Sustainability of SHGs

Table 3. Distribution of the Respondents Based on their Entrepreneurial Behaviour

\begin{tabular}{|c|l|c|c|l|c|c|}
\hline \multirow{2}{*}{ S1.No } & \multicolumn{1}{|c|}{ Category } & \multicolumn{2}{c|}{ Men (n=45) } & \multicolumn{2}{c|}{ Category } & \multicolumn{2}{c|}{ Women (n=45) } \\
\cline { 3 - 4 } \cline { 5 - 6 } & & F & \% & & F & \% \\
\hline 1 & Low & 7 & 15.55 & Low & 16 & 35.55 \\
\hline 2 & Medium & 27 & 60.00 & Medium & 24 & 53.34 \\
\hline 3 & High & 11 & 24.45 & High & 5 & 11.11 \\
\hline & $\begin{array}{l}\text { Mean=5.51 } \\
\text { SD = 0.96 }\end{array}$ & & $\begin{array}{l}\text { Mean }=4.53 \\
\text { SD }=0.94\end{array}$ & & \\
\hline
\end{tabular}

F-Frequency, \%- Percentage

Comparison of Performance of Men and Women Groups with Dependent Variables

The result of ANOVA which is presented in Table 4 indicates that the men and women SHG members showed significant difference in their entrepreneurial behaviour. This may be because the men respondents who belonged to age group $>55$ of years had low competitive entrepreneurial skill. The women respondents who belonged to age group years 35-55 exhibited medium entrepreneurial behaviour. 
Table 4. Result of the ANOVA between Men and Women SHGs with respect to Dependent Variables.

\begin{tabular}{|c|c|c|c|c|c|}
\hline S1.No. & Dependent Variable & $\begin{array}{c}\text { Mean } \\
\text { Score(Men) }\end{array}$ & $\begin{array}{c}\text { Mean Score } \\
\text { (Women ) }\end{array}$ & $\begin{array}{c}\text { F- } \\
\text { value }\end{array}$ & $\begin{array}{c}\text { Infer- } \\
\text { ence }\end{array}$ \\
\hline 1 & Managerial efficiency & 64.32 & 59.56 & 2.95 & $\mathrm{NS}$ \\
\hline 2 & Sustainability & 65.4 & 66.5 & 0.72 & $\mathrm{NS}$ \\
\hline 3 & $\begin{array}{c}\text { Entrepreneurial be } \\
\text { aviour }\end{array}$ & 5.51 & 4.53 & 4.2 & $\mathrm{~S}^{*}$ \\
\hline
\end{tabular}

* Significant at 5\% level

\section{CONCLUSION}

The present study revealed that majority of the men and women respondents had medium level of managerial efficiency, sustainability and entrepreneurial behaviour. But the men SHG members exhibited slightly more managerial efficiency and entrepreneurial behavior than women SHGs. Regarding the sustainability of SHGs also, men SHGs were more sustainable. ANOVA revealed that significant difference was observed between men SHGs and women SHGs with respect to entrepreneurial behaviour only.

\section{REFERENCES}

Dabson, B. \& Malikin, J. (2003), Mapping Rural Entrepreneurship. W.K.Kellong Foundation and Corporation for Enterprise Development, New York, $225 p$.

Drucker, P. F.(1985). Innovation and Entrepreneurship. Harper Business, New York, 229p.
Kahan, D. (2012). Entrepreneurship in farming. Farm management extension guide.

Kumar, T.R. (2007). A multi-dimensional analysis of apiculturists in Kollam and Thiruvananthapuram district. unpublished M.Sc.(Ag.) Thesis, Kerala Agricultural University, Thrissur, 109p.

NABARD.(1995), Linking SHGs with Banks - An Indian Experience. NABARD, Bombay, pp. 1-25

Pandey, G. (2013). Agripreneurship education anddevelopment: Need of the day. Asian Resonance. 2(4): 153156.

Sreedaya, G.S. (2000). Performance Analysis of Self Help Groups Involved in Vegetable Production in Thiruvananthapuram district. Unpublished M.Sc (Ag) Thesis, Kerala Agricultural University, Thrissur.136p. 